Osmaniye Korkut Ata University
Journal of Natural and Applied Sciences
Volume 3, Issue 2, 164-171, 2020

\title{
KOP Bölgesinde Manda Yetiştiriciliği ve Önemi
}

\author{
Orhan ERMETIN ${ }^{1 *}$ \\ Yozgat Bozok Üniversitesi, Ziraat Fakültesi, Zootekni Bölümü, 66900 Yozgat \\ ${ }^{1}$ https://orcid.org/0000-0002-3404-0452 \\ *Sorumlu yazar: orhan.ermetin@yobu.edu.tr
}

\section{Derleme}

\section{Makale Tarihçesi:}

Geliş tarihi: 18 Nisan 2020

Kabul tarihi: 15 Temmuz 2020

Online Yayınlanma: 15 Aralık 2020

\section{Anahtar Kelimeler:}

Anadolu Mandası

KOP illeri

Manda yetiştiriciliği

\section{ÖZET}

Türkiye'de yetiştirilen mandalar, rrk olarak Nehir mandalarının bir alt grubu olan Akdeniz mandalarından köken almakta olup, Anadolu Mandası olarak adlandırılmış̧ır. Anadolu mandaları, Türkiye şartlarına binlerce yılda çok iyi adapte olmuş ve kendine özgü karakteristik özellikler geliştirmiştir. Genel rengi siyah olup, yay şeklinde geriye kavisli boynuza sahiptirler. Ortalama süt verimi $1000 \mathrm{~kg} / \mathrm{yll}$, ortalama laktasyon süresi ise 250 gündür. Mandalar, sığıılara kıyasla daha az et ve süt vermelerine rağmen, et ve süt kalitesinin yüksekliği ile hastalıklara, kötü beslenme ve çevre şartlarına dayanıklılı̆̆ gibi avantajları bulunmaktadır. Manda sütü yağ ve toplam kuru madde açısından çok zengin olup, son yıllarda manda sütünden yapılmış yoğurt, kaymak ve peynir gibi ürünlere talep gittikçe artmaktadır. Ülkemizde son yıllarda tüketici talebi ile Tarım ve Orman Bakanlı̆̆ının destekleri ile manda yetiştiriciliği yaygınlaş̧maktadır. KOP (Konya Ovası Projesi) Bölgesi; 4.307,408 kişilik nüfusu, 95,945 km² yüzölçümü ile Türkiye'nin \%12,24'ünü oluşturan önemli tarımsal üretim alanlarından biridir ve tarımın bölge ekonomisinde ağırlıklı etkisi vardır. Orta Anadolu Bölgesinde 8 ilden oluşan KOP illeri içinde manda sayısı en fazla olan il Yozgat olup, ilde 4133 baş manda varlığından yılda 1447 ton süt elde edilmektedir. Yozgat ilini Aksaray (1381 baş), Konya ( 865 baş), Kırıkkale (482 baş) ve Kırşehir (221 baş) takip etmektedir. KOP Bölgesi illerinde manda yetiştiriciliğinin mevcut durumu incelenerek, sürdürülebilir manda yetiştiriciliği için bakış açısı ve öneriler sunulmuştur.

\section{Water Buffalo Breeding in KOP Region and Its Importance}

\section{Review}

Article History:

Received: 18 April 2020

Accepted: 15 July 2020

Published online: 15 December 2020

\section{Keywords:}

Anatolian buffaloes

KOP provinces

Water buffalo breeding

\begin{abstract}
The water buffalo grown in Turkey, which is a subgroup of the race as river buffalo is on the origin of the Mediterranean, was named Anatolian Buffaloes. Anatolian buffaloes thousands of years have been very well adapted to conditions in Turkey and has developed its own unique characteristics. The overall colour is black and has a curved horn in the form of an arc. The average milk yield is 1000 $\mathrm{kg} /$ year and the average lactation period is 250 days. Although water buffaloes give less meat and milk compared to cattle, they have the advantages of higher meat and milk quality and resistance to diseases, poor nutrition and environmental conditions. Water buffalo milk is very rich in terms of fat and total dry matter and in recent years demand for products such as yoghurt, cream and cheese made from buffalo milk has been increasing steadily. In recent years, with the support of the Ministry of Agriculture and Forestry and consumer demand, the growth of water buffalo has become widespread in our country. KOP (Konya Plain Projects) Region; A population of $4.307,408$, with its $95,945 \mathrm{~km}^{2}$ area constituting $12,24 \%$ of Turkey and is one of the major agricultural production areas are mainly agricultural impact on the region's economy. Yozgat has the largest number of
\end{abstract}


water buffalo among of 8 KOP provinces. There are 4133 heads of water buffaloes and 1447 tons of milk is obtained per year in Yozgat. Aksaray (1381 heads), Konya (865 heads), Kırıkkale (482 heads) and Kırşehir (221 heads) respectively. By examining the current status of water buffalo breeding in the KOP Region provinces, perspectives and suggestions for sustainable water buffalo breeding are presented.

To Cite: Ermetin O. KOP Bölgesinde Manda Yetiştiriciliği ve Önemi. Osmaniye Korkut Ata Üniversitesi Fen Bilimleri Enstitüsü Dergisi 2020; 3(2): 164-171.

\section{Giriş}

Kalkınma Bakanlığı'nın bağlı bir kuruluşu olarak 2011 yılında faaliyetlerine başlayan KOP (Konya Ovas1 Projesi) Bölge Kalkınma İdaresi Başkanlığı'nın ilk etapta Aksaray, Karaman, Konya ve Niğde illerinden oluşan görev sahasına 2016 yılı Haziran ve Eylül aylarında yayınlanan Bakanlar Kurulu kararları ile Nevşehir, Yozgat, Kırşehir ve Kırıkkale illeri eklenmiş ve Başkanlığın sorumluluk sahasında bulunan il sayıs1 sekize çıkmıştır. KOP Bölgesi'nin toplam yüzölçümü $95,580 \mathrm{~km}^{2}$ olup, bölge nüfusu da 4,5 milyonu geçmiştir [1]. KOP illerinin nüfusları, yüzölçümleri ve ilçe sayıları Tablo 1'de verilmiştir.

Tablo 1. KOP illerinin nüfusları, yüzölçümleri ve ilçe sayıları [2]

\begin{tabular}{|c|c|c|c|}
\hline $\begin{array}{c}\text { KOP } \\
\text { İLLERİ }\end{array}$ & NÜFUS & $\begin{array}{c}\text { YÜZÖLÇÜMÜ } \\
\left(\mathbf{k m}^{2}\right)\end{array}$ & $\begin{array}{c}\text { İLÇE } \\
\text { SAYISI }\end{array}$ \\
\hline Aksaray & 416,367 & 7,966 & 8 \\
\hline Karaman & 253,279 & 8,869 & 6 \\
\hline Kırıkkale & 283,017 & 4,570 & 9 \\
\hline Kırşehir & 242,938 & 6,530 & 7 \\
\hline Konya & $2.232,374$ & 40,814 & 31 \\
\hline Nevşehir & 303,010 & 5,392 & 8 \\
\hline Niğde & 362,861 & 7,365 & 6 \\
\hline Yozgat & 421,200 & 14,074 & 14 \\
\hline $\begin{array}{l}\text { KOP } \\
\text { Toplam }\end{array}$ & $4.515,046$ & 95,580 & 89 \\
\hline Türkiye & 83.154,997 & 783,562 & 972 \\
\hline TR/KOP \% & 5,43 & 12,20 & 9,16 \\
\hline
\end{tabular}

KOP Bölgesi Türkiye yüzölçümünün \%12,20'sine, çayır mera varlığının da \%13,07'sine ve tarım alanlarının \%12,33'üne sahiptir. KOP Bölgesinde çayır mera varlığı 19.104,850 dekar olup, değişen iklim ve toprak özelliklerine ve kullanım durumuna bağlı olarak, illerdeki mera alanları ile bu meraların verimliliklerinde farklılıklar bulunmaktadır. KOP bölgesi illerinde en fazla mera alanı Konya ilinde olup (8.164,440 da), bu ili sirasiyla Niğde $(2.510,530$ da) ve Yozgat $(2.400,000$ da) illeri takip etmektedir [2].
Meteoroloji Genel Müdürlüğünün uzun yıllar (1981-2018) ölçümlerine göre KOP illerinin ortalama sıcaklığ $11,3 \quad{ }^{\circ} \mathrm{C}$ olup, Türkiye ortalamasından $\left(13,2{ }^{\circ} \mathrm{C}\right)$ düşüktür. Bölgede en az yağış alan il Konya $(323,3 \mathrm{~mm})$ ve en fazla yağı̣s alan il, Yozgat (562,5 mm) ilidir [3].

Bölge halkının, bölge içi ve bölgeler arası gelişmişlik farklarını azaltmayı amaçlayan KOP Bölge Kalkınma İdaresi Başkanlığı, bölgenin rekabet gücünü geliştirerek ekonomik ve sosyal yapıyı güçlendirmek ve vatandaşlarımızın refah düzeyini yükseltmeyi temel öncelikleri arasında görmektedir. $\mathrm{Bu}$ öncelikleri gerçekleştirmek, kalkınmasını hızlandırmak için bölge illeri için hazırlanan KOP Eylem Planı şu anda yürürlüktedir. KOP Eylem Planı'nın temel amacı bölgede kapsamlı bir dönüşümü gerçekleştirmektir. Bu çerçevede tarımsal yapıda değişimi ve sürdürülebilirliği sağlayarak; sanayi, ticaret, ulaşım, enerji gibi sektörleri güçlendirmek, eğitim, sağlık, kültür ve diğer sosyal hizmetlere erişilebilirliği artırmak, bölge içi ve bölgeler arası gelişmişlik farklarını azaltmak, yenilikçi bir yaklaşımla bölgenin rekabet gücünü geliştirmek, bölgenin ekonomik ve sosyal kapasitesini güçlendirmek ve refah düzeyini yükseltmek temel önceliklerdir [4].

KOP Bölge Kalkınma İdaresi Başkanlığı, sulama ve hayvancılık projeleri ile tarım sektörü başta olmak üzere, enerji, ulaşım, bilişim, sanayi, ticaret ve turizm gibi iktisadi sektörlerde, kültür, sanat, gençlik ve toplumun dezavantajlı kesimlerine yönelik yürüttüğü sosyal içerme ve kalkınma projeleri ile de sosyal sektörlerde faaliyetlerini sürdürerek, entegre bir bölgesel kalkınma sürecini yürütmektedir.

\section{Manda Yetiştiriciliği ve Önemi}

Evcil ve yabani olarak 70'in üzerinde ayrı rrk1 bulunan mandalardan evcil olanlar "Nehir (Irmak) Mandası" ve "Bataklık Mandası" olarak iki gruba ayrılır. Orijinleri Hindistan olan nehir mandaları, daha çok et ve süt üretmek için yetiştirilen kombine verimli ırklardır. Türkiye'deki mandalar, nehir mandalarının alt grubu olan Akdeniz 
mandalarından köken alıp, "Anadolu Mandası" olarak adlandırılmaktadır. Genel rengi siyah olup, yay şeklinde geriye kavisli boynuza sahiptirler [5, 6]. Geçmişte ülkemizde yetiştirilen mandalardan çeki gücü olarak yararlanılmış olsa da, günümüzde et ve süt verimi yönünden yararlanılmaktadır.

Manda, bugüne kadar diğer çiftlik hayvanlarına kıyasla fazla değer verilmemiş olmasına rağmen son yıllarda gerek Türkiye'de gerekse birçok ülkede çeşitli özellikleri ve verimleri sebebiyle üzerinde önemle durulan bir hayvandır. Özellikle şartları müsait olan ülkelerde manda yetiştiriciliğine gerekli önem verilmeye başlanmıştır. Mandaya bu önemi kazandıran özellikleri arasında; doğa şartlarına ve hastalıklara karşı dayanıklılığ 1 , kalitesiz kaba yemleri et ve süte dönüştürebilmesi, yetiştirme giderlerinin sığıra göre daha düşük olması, yemleme konusundaki kanaatkârlığı ile önem arz etmektedir [6].

Ömürleri 30 yıla kadar çıkan mandalar, sığıra göre geç gelişen bir hayvandır ve gelişmesi altı yaşına kadar devam etmektedir. Cinsi olgunluğa ulaşma yaş1 sığırdan geçtir. Manda düveleri 13-14 aylık yaşta cinsi olgunluğa ulaşır. Bu nedenle manda düveleri 22-24 aylık yaşta tohumlanabilir. Erkek mandalar ise 20-21 aylık yaştan itibaren 5-6 yaşlarına kadar boğa olarak kullanılabilmektedir $[7,8,9]$.

Manda ineklerinde kızgınlık sığırdaki kadar belirgin değildir ve kızgınlık dönemi daha sakin geçer. Mandaların gebelik süreleri ırk, iklim ve yetiştirildiği ülke gibi durumlara göre 299-346 gün arasında değişmekle birlikte ortalama olarak 315-319 gündür. Doğum ortalama 5 saat sürer ve çoğu zaman günün sakin saatlerinde, gece ve sabaha karşı, genellikle yardıma gerek kalmaksızın gerçekleşir. Mandalar genellikle tekiz yavru doğururlar [8].

Mandalarda ergin deri kalınlığ 6,0-7,6 mm olup, sığır derisinden daha kalındır. Ancak kıl örtüsü ve deri altı ter bezleri sığır derisine göre 1/10 oranında daha azdır. Ter bezlerinin ve k1 örtüsünün azlığı nedeniyle, yazın sıcak aylarda, beden 1sısını kendiliğinden ayarlayamaz, rahatsız olur; bunu sağlamak için de suda yüzme, bataklık veya çamura girme ihtiyacı duyar. Bunun yanında deri kıl yoğunluğunun az olması nedeniyle soğuk havalara karşı dirençleri sığırlardan daha azdır $[10,11]$.

Özellikle düşük gelirli ülkelerde et, süt, deri ve işgücü olarak faydalanılan mandalar ekonomik olarak önemli bir çiftlik hayvanıdır. Türkiye'de mandaların süt verimleri, bakım ve besleme şartlarına göre oldukça farklılık göstermekle birlikte ortalama süt verimi $1000 \mathrm{~kg} / \mathrm{y} 1$ l, ortalama laktasyon süresi ise 250 gündür $[9,12]$. Manda sütünün besin madde içeriği inek sütünden daha yüksektir. Manda sütü inek sütüne oranla daha az su, daha çok kuru madde, mineral, yağ ve protein içermekte olup, toplam kuru maddelerin daha yüksek olması nedeniyle krema, tereyağı ve peynir gibi süt ürünlerinin verimini artırmaktadır. Yüksek kuru maddenin yanında yüksek yağ ve kalori içermesi, manda sütünün üstün ve ayırıcı özellikleri olarak değerlendirilmektedir [13].

İnek sütünün 100 gramından 70 kalori elde edilirken, manda sütünden 100 kalori elde edilmektedir. Yağ globüllerinin daha büyük olması, kat1 yağların yüksek oranda bulunması tereyağının yayık yapılmasını ve kremanın ayrılmasını kolaylaştırmaktadır. Manda sütünden elde edilen yăg yüzdesi $(7,8)$ inek sütünden elde edilenden $(3,65)$ önemli derecede daha yüksektir [14]. İnek sütü ile karşılaştırıldığında, manda sütünün kolesterol düzeyi daha düşük, tokoferol (vit-E) düzeyi daha yüksektir. Manda sütü, beyaz rengi, yüksek yă̆ içeriği ve lezzet yönüyle tüketicinin tercih ettiği bir süttür. Peroksidaz aktivitesi daha yüksek olduğu için manda sütü daha uzun süre saklanabilir. Sütte kalsiyum içeriği daha yüksek, kalsiyum: fosfor oranı daha uygun, sodyum ve potasyum düzeyinin inek sütünden daha düşük olması yeni doğanlar için daha iyi bir besinsel destek sağlamaktadır. Manda sütü inek, koyun ve keçi gibi sütlerle karşılaştırıldığında birçok özellik bakımından daha üstün olduğu görülmektedir [6,10,15,16,18,19]. Mandalar uyum kabiliyetleri, düşük kalitedeki besin maddeleri değerlendirebilmeleri, et ve sütlerinde düşük kolesterol ve daha yüksek doymamış yağ asitleri içeren yağlar içermeleri bakımından genetik biyoçeşitlilik için vazgeçilmez hayvanlardır [17]. Manda sütünün bileşiminin, diğer çiftlik hayvanlarından elde edilen sütlerle karşılaştırması Tablo 2'de verilmiştir.

Tablo 2. Manda sütü bileşiminin diğer bazı çiftlik hayvanlarına ait süt içerikleriyle karşılaştırılması (\%) $[6,18,19]$

\begin{tabular}{lccrrrr}
\multicolumn{1}{c}{ Tür } & Su & $\begin{array}{c}\text { Kuru } \\
\text { madde }\end{array}$ & Protein & Yăg & Laktoz & $\begin{array}{c}\text { Mineral } \\
\text { madde }\end{array}$ \\
\hline Manda & 82,0 & 17,7 & 4,15 & 7,85 & 4,80 & 0,77 \\
\hline İnek & 87,5 & 12,4 & 3,40 & 3,65 & 4,65 & 0,75 \\
\hline Koyun & 82,9 & 17,2 & 5,40 & 6,25 & 4,55 & 0,88 \\
\hline Keçi & 87,1 & 13,0 & 3,70 & 4,10 & 4,45 & 0,80 \\
\hline
\end{tabular}


Et özellikleri bakımından değerlendirildiğinde manda eti; insanların tüketebileceği en sağlıklı kırmızı etlerden birisidir. Kalorisi ve kolesterolü düşüktür. İntramuskuler yağ tabakası daha az olduğu veya daha fazla pigmentasyondan dolay1 koyu kırmızı renktedir [9]. Sığır eti ve manda etinin bileşenleri Tablo 3'de verilmiştir.

Tablo 3.Sı̆̆ır eti ile manda etinin karşılaştırılması (100 gr) [9]

\begin{tabular}{lcc}
\hline \multicolumn{1}{c}{ Bileşenler } & Sı̆̆ır eti & Manda eti \\
\hline Kalori (kcal) & 289 & 131 \\
Protein (gr) & 24 & 26,8 \\
Yağ (gr) & 21 & 1,8 \\
Kolesterol (mg) & 90 & 61 \\
Mineral (mg) & 584 & 641,8 \\
Vitamin (mg) & 18,5 & 21 \\
\hline
\end{tabular}

\section{Türkiye'de Manda Yetiştiriciliği}

Türkiye'de manda yetiştiriciliği, yağışı bol olan bölgeler ile akarsu ve gölet gibi su kaynağı olan Karadeniz, Marmara ve Doğu Anadolu bölgesinde yoğun olarak yapılmaktadır (Şekil 1). Bölgeler bazında dağılım incelediğinde \%37,2'lik payla geleneksel manda yetiştiricisi illerin yoğunlukta olduğu Karadeniz Bölgesi (43,846 baş) ilk sırada yer almaktadır. Karadeniz Bölgesi'ni \%17'lik payla Marmara bölgesi, bunu Doğu Anadolu $\% 15,5$ ve dördüncü sırada da İç Anadolu Bölgesi $\% 12^{\prime}$ lik payla takip etmektedir. Geri kalan bölgelerimizin pay1 \%10'un altında olup özellikle Akdeniz Bölgesi'nin manda varlığı oldukça düşüktür [20, 21]. Manda yetiştiriciliği ülkemizde, yağış azlığı, küresel iklim değişikliği ve süt sığırlarına nazaran daha az süt verimleri gibi sebeplerden dolayı, yıllar itibariyle azalsa da son yıllarda yetiştiricilere verilen üretim desteklemelerinden dolayı sayı ve verim bakımından artış gözlenmektedir [16]. Türkiye'deki manda sayıs1 1990 yılında 371,000 baş iken 2000 yllında 146,000, 2010 y1lında 84,726 ve 2019 yllında ise 184,192 baştır [2].

TÜRKIYE MANDA VARLIĞI DAĞILIMI

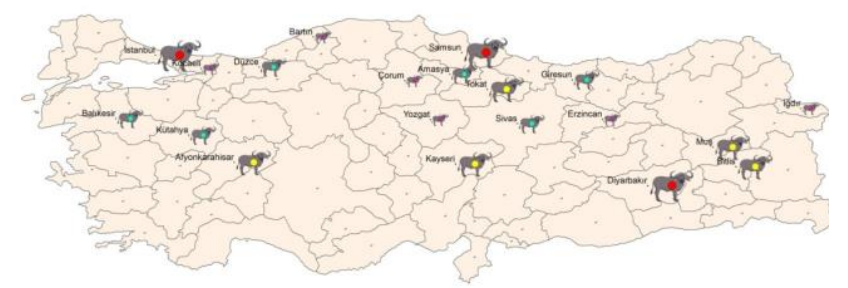

Türkiye de 81 ilin 76'sında manda yetiştiriciliği yapılmakta olup, en fazla manda varlığına sahip 20 ilin Türkiye haritasında dağılımı Şekil 1'de ve sıralamas1 Tablo 4'de verilmiştir. Tablo 4 incelendiğinde en fazla manda sayısına sahip olan ilin Samsun (22,050 baş) olduğu görülmektedir. İldeki mandacılık genelde süt üretimi için yapılmakta olup 10,253 ton süt üretimi gerçekleştirilmektedir. Özellikle Kızılırmak deltası ve bölgenin yüksek yağış alması da mandacilik merkezi olmasinda etkendir. İstanbul'da son yıllarda artan manda yetiştiriciliği de süt üretimi ve büyükşehirde yaşayan nüfusun manda sütüne olan talebini karşılamaktadır. Afyonkarahisar ilinde ise manda sütü geleneksel olarak üretilen ve marka haline gelen Afyon kaymağ 1 şeklinde tüketilmektedir. Kayseri'de ise et üretimi ön plana çıkmakta ve meşhur Kayseri pastırması üretiminin bir kısmında özellikle manda eti kullanılmaktadır. İşlenmiş et ürünleri sanayinin gelişimine paralel olarak kayda değer bir gelişim elde edilmiştir. Doğu ve Güneydoğu Anadolu Bölgelerinde de Diyarbakır, Muş ve Bitlis lokal merkezler olarak faaliyete devam etmişlerdir. Tarım ve Orman Bakanlığının son y1llarda manda üretimine verdiği destekler ve Manda Yetiştirici Birliklerinin sayısının artmasına paralel olarak daha önce lokal olarak yapılan manda yetiştiriciliğinin, birçok ilde teşkilatlanarak ticari üretim yapar hale geldiği gözlenmektedir [21].

Türkiye'de manda yetiştiriciliği yapılmayan Adıyaman Muğla, Siirt, Tunceli ve Karaman illeri haricinde tüm illerde yaygın ve lokal olarak yetiştirilen Anadolu mandası 1rk1 mandalar bulunmaktadır [2]. Türkiye'de yaklaşık 79,357 ton manda sütü üretilip özellikle yoğurt, kaymak ve tereyağı olarak tüketilmektedir. Kırmızı et kaynağ 1 olarak manda eti tüketimi 2019 yılı için yaklaşık 73 ton olarak belirtilmiştir [2]. İtalya'da laktasyon süt veriminin $2200 \mathrm{~kg}$ olduğu belirtilmektedir [22]. Genelde ekstansif şartlarda yetiştirilen Anadolu mandasının süt veriminin düşük olmasının nedenleri olarak genotip, besleme ve çevre şartlarının etkisi olduğu söylenebilir.

Şekil 1. Türkiye'de en fazla manda varlığına sahip 20 ilin dağılımı [21] 
Tablo 4. Türkiye'de en fazla manda varlığına sahip 20 ildeki manda sayıları ve süt verimleri [2]

\begin{tabular}{|c|c|c|c|c|c|}
\hline İLLER & $\begin{array}{c}\text { Toplam } \\
\text { Manda } \\
\text { Sayısı } \\
\text { (baş) }\end{array}$ & $\begin{array}{c}\text { Türkiye'de } \\
\text { Yüzdelik Sırası }\end{array}$ & $\begin{array}{l}\text { Sağılan Hayvan } \\
\text { Sayısı (Baş) }\end{array}$ & $\begin{array}{l}\text { Üretilen Manda } \\
\text { Sütü (kg) }\end{array}$ & $\begin{array}{c}\text { Sağılan } \\
\text { Hayvan } \\
\text { Başına Süit } \\
\text { Verimi (kg) }\end{array}$ \\
\hline Samsun & 22,050 & 11,97 & 10,356 & $10.252,915$ & 990 \\
\hline Diyarbakır & 17,295 & 9,39 & 8,296 & $7.880,906$ & 950 \\
\hline İstanbul & 15,844 & 8,60 & 7,957 & $8.545,657$ & 1,074 \\
\hline Tokat & 11,743 & 6,38 & 4,410 & $4.185,118$ & 949 \\
\hline Bitlis & 10,242 & 5,56 & 4,560 & $4.195,218$ & 920 \\
\hline Muş & 7,078 & 3,84 & 3,382 & $3.270,636$ & 967 \\
\hline Sivas & 7,029 & 3,82 & 2,556 & $2.300,472$ & 900 \\
\hline Kayseri & 7,020 & 3,81 & 2,799 & $2.770,565$ & 990 \\
\hline Balıkesir & 6,369 & 3,46 & 3,927 & $3.977,727$ & 1,013 \\
\hline Afyonkarahisar & 6,301 & 3,42 & 2,802 & $3.081,892$ & 1,100 \\
\hline Amasya & 5,064 & 2,75 & 2,133 & $2.220,703$ & 1,041 \\
\hline Giresun & 4,457 & 2,42 & 1,825 & $1.790,580$ & 981 \\
\hline Bartın & 4,183 & 2,27 & 1,718 & $1.563,244$ & 910 \\
\hline Yozgat & 4,133 & 2,24 & 1,447 & $1.446,720$ & 1,000 \\
\hline Kütahya & 4,014 & 2,18 & 1,724 & $1.680,832$ & 975 \\
\hline Düzce & 3,867 & 2,10 & 1,193 & $1.113,442$ & 933 \\
\hline Çorum & 3,689 & 2,00 & 1,450 & $1.409,682$ & 972 \\
\hline Iğdır & 2,763 & 1,50 & 1,014 & $1.014,260$ & 1,000 \\
\hline Bursa & 2,710 & 1,47 & 849 & $1.082,666$ & 1,275 \\
\hline Kocaeli & 2,483 & 1,35 & 876 & 788,715 & 900 \\
\hline TÜRKIYYE & 184,192 & 100,00 & 79,333 & $\mathbf{7 9 . 3 5 6 , 8 8 1}$ & 1,000 \\
\hline
\end{tabular}

\section{KOP İllerinde Manda Yetiştiriciliği}

Konya, Aksaray, Karaman, Niğde, Nevşehir, Yozgat, Kırıkkale ve Kırşehir illerinden oluşan KOP illerindeki manda sayılarına bakıldığında, en fazla manda sayısının Yozgat ilinde olduğu görülmekte olup sirasiyla, Aksaray, Konya ve Kırıkkale illerinin takip ettiği görülmektedir. KOP illeri manda varlığ 1 ve manda sütü üretimi Tablo 5 'de verilmiştir.

Tablo 5'den de anlaşılacağ 1 üzere KOP illeri içinde Yozgat ilinde 2019 yılı TUIK verilerine göre toplam 4,133 baş mandadan 1,447 ton manda sütü elde edilmektedir. Aksaray'da manda varlığ 1,381 , Konya'da ise 865 baştır. Karaman ilinde ise manda yetiştiriciliği yapılmamaktadır.

KOP illeri içerisinde en çok manda sayısına sahip il olan Yozgat'a ayrıca değinmek gerekir. Yozgat ili coğrafi ve iklimsel koşulları itibariyle ve mevcut mera alanlarının çokluğuyla hayvancılık yapmaya oldukça müsait bir konumdadır. Yozgat ili son verilere göre; 245,825 baş toplam büyükbaş sayıs1 ile KOP illeri arasında Konya'dan sonra 2.,
Türkiye'de ise 25. sırada yer almaktadır. Toplam 4,133 baş manda varlığ ile de KOP illeri arasında 1., Türkiye'de ise 14. sırada yer almaktadır [2].

Yozgat ilinde manda yetiştiriciliği geleneksel olarak dağ köylerinde yapılmakta olup, elde edilen sütleri yoğurt ve kaymak olarak pazarlarda ve yerel marketlerde pazarlamaktadırlar. İlde bulunan Damızlık Manda Yetiștiricileri Birliğine üye 175 yetiştirici, ilin 13 ilçesinde ve 58 köyünde yetiştiricilik yapmaktadır. Çandır ilçesi haricinde tüm ilçelerinde manda yetiştiriciliği yapılmakta olup, Merkez, Sorgun ve Kadişehri en fazla mandaya sahip ilçelerdir (Tablo 6). 
Tablo 5. KOP İlleri manda varlığı ve manda sütü üretimi[2]

\begin{tabular}{lrrrrr} 
KOP İLLERI & $\begin{array}{c}\text { Toplam } \\
\text { Manda Sayısı } \\
\text { (baş) }\end{array}$ & $\begin{array}{c}\text { Türkiye Manda } \\
\text { Varlığına Göre } \\
(\mathbf{\%})\end{array}$ & $\begin{array}{c}\text { Sağılan Hayvan } \\
\text { Sayıs } \\
\text { (Baş) }\end{array}$ & $\begin{array}{c}\text { Üretilen } \\
\text { Manda Sütüi } \\
\text { (kg) }\end{array}$ & $\begin{array}{c}\text { Sağılan Hayvan } \\
\text { Başına Süt } \\
\text { Verimi (kg) }\end{array}$ \\
\hline Yozgat & 4,133 & 2,24 & 1,447 & $1.446,720$ & 1,000 \\
Aksaray & 1,381 & 0,75 & 491 & 625,356 & 1,274 \\
Konya & 865 & 0,47 & 373 & 478,932 & 1,284 \\
Kırıkkale & 482 & 0,26 & 167 & 162,184 & 971 \\
Kırşehir & 221 & 0,12 & 78 & 72,524 & 930 \\
Nevşehir & 75 & 0,04 & 9 & 8,714 & 968 \\
Niğde & 31 & 0,02 & 8 & 8,100 & 1,013 \\
Karaman & 0 & 0,00 & 0 & 0 & 0 \\
TÜRKIYE & $\mathbf{1 8 4 , 1 9 2}$ & $\mathbf{1 0 0 , 0 0}$ & $\mathbf{7 9 , 3 3 3}$ & $\mathbf{7 9 . 3 5 6 , 8 8 1}$ & $\mathbf{1 , 0 0 0}$ \\
\hline
\end{tabular}

Tablo 6. Yozgat ili ve ilçeleri manda varlığı dağılımı [2]

\begin{tabular}{|c|c|c|c|c|c|c|c|c|}
\hline İLÇELER & $\begin{array}{c}2 \text { ve } \\
\text { daha } \\
\text { yukarı } \\
\text { yaşta } \\
\text { (İnek) }\end{array}$ & $\begin{array}{c}1 \text { - } 2 \\
\text { yaş } \\
\text { arası } \\
\text { dişi } \\
\text { (Düve) }\end{array}$ & $\begin{array}{c}2 \text { ve } \\
\text { daha } \\
\text { yukarı } \\
\text { yaşta } \\
\text { (Boğa) }\end{array}$ & $\begin{array}{c}2 \text { ve } \\
\text { daha } \\
\text { yukarı } \\
\text { yaşta } \\
\text { (Öküz) }\end{array}$ & $\begin{array}{c}\text { 1-2 yaş } \\
\text { arası } \\
\text { erkek } \\
\text { (Tosun) }\end{array}$ & $\begin{array}{c}1 \\
\text { yaşından } \\
\text { küçük } \\
\text { (Erkek) }\end{array}$ & $\begin{array}{c}1 \\
\text { yaşından } \\
\text { küçükk } \\
\text { (Dişi) }\end{array}$ & TOPLAM \\
\hline Akdağmadeni & 235 & 85 & 52 & 44 & 43 & 74 & 68 & 601 \\
\hline Aydıncık & 60 & 25 & 10 & 0 & 5 & 8 & 22 & 130 \\
\hline Boğazlıyan & 5 & 8 & 2 & 0 & 2 & 4 & 4 & 25 \\
\hline Kadışehri & 370 & 73 & 132 & 0 & 80 & 81 & 86 & 822 \\
\hline Merkez & 356 & 199 & 15 & 0 & 24 & 151 & 175 & 920 \\
\hline Saraykent & 15 & 5 & 2 & 0 & 15 & 10 & 8 & 55 \\
\hline Sarıkaya & 80 & 30 & 20 & 0 & 21 & 18 & 15 & 184 \\
\hline Sorgun & 350 & 100 & 26 & 0 & 80 & 140 & 150 & 846 \\
\hline Yenifakılı & 0 & 0 & 0 & 0 & 0 & 3 & 0 & 3 \\
\hline Yerköy & 11 & 0 & 0 & 0 & 0 & 0 & 0 & 11 \\
\hline Çayıralan & 22 & 9 & 4 & 0 & 5 & 4 & 6 & 50 \\
\hline Çekerek & 140 & 84 & 80 & 0 & 45 & 61 & 56 & 466 \\
\hline Şefaatli & 0 & 17 & 0 & 0 & 3 & 0 & 0 & 20 \\
\hline TOPLAM & 1,644 & 635 & 343 & 44 & 323 & 554 & 590 & 4,133 \\
\hline
\end{tabular}

İşletmeler genelde küçük aile işletmesi şeklinde olup, işletme başina 10,23 baş dişi manda düşmekte ve meraya dayalı bir beslenme şekli uygulanmaktadır. İşletmeler sağdıkları sütü yoğurt, tereyağı ve kaymak olarak değerlendirmekte, yerel pazar ve marketlerde pazarlamaktadır. Tarım ve Orman Bakanlığının damızlık manda ve malak destekleri ile son yıllarda manda sayısında artış olmuştur.

\section{Sonuç ve Öneriler}

Konya, Karaman, Aksaray, Niğde, Nevşehir, Kırşehir, Yozgat ve Kırıkkale illerinin uygun coğrafi yapısı, geniş tarım arazilerine sahip olması dolayisiyla artan ülke nüfusunun beslenme ihtiyaçlarını karşılaması nedeniyle Konya Ovası
Projesi ülke için stratejik önem taşımakta ve bu potansiyel büyük umut vaat etmektedir. Konya Ovası Projesi, bölgesel gelişmeyi hızlandırmak ve bölgesel gelişmenin sürdürülebilirliğini sağlamanın yanı sıra tarım sektörü ile ülke ekonomisine sağlayacağı katkılarla önemli bir yere sahiptir.

Doğa şartlarına ve hastalıklara karşı dayanıklılığ kalitesiz kaba yemleri et ve süte dönüştürebilmesi, yetiştirme giderlerinin sığıra göre daha düşük olması ile süt ve süt ürünlerinin daha yüksek ücretlerde satılması gibi avantajlarından dolay1 manda yetiştiriciliği KOP illerinin uygun bölgelerinde devam ettirilmelidir.

Kırsal alanda mandacilık yapan üreticilere, ulusal bazda desteklemeler yanında yerel otoriteler 
tarafindan verilecek teşvik ve özendirici faaliyetler ile sürdürülebilirlik sağlanarak, kırsal alanda gelir seviyesi artırılmalıdır. Hayvancılığın gelişmesi ile köyden kente göç önlenecek, üreticiler geleneksel şekilde yaptıkları mandacılık faaliyetlerini daha teknik modern şartlarda devam etme olanağı elde edeceklerdir. Manda yetiştiriciliğine uygun olan bölgelerde damılık materyal dağıtımı, teşvik yarışmaları ve festivaller gibi etkinliklerde destekleme kapsamına alınarak farkındalığın artması sağlanmalıdır. Manda yetiştiricilerine yönelik, bakım, besleme, sağım hijyeni gibi konularda eğitimler verilmeli, mevcut barınakların iyileştirilmesi için desteklemeler ve projeler yürütülmelidir.

Yozgat ilinde yürütülmekte olan manda yetiştiriciliğinin marka değeri olabilecek faaliyetlerin ön plana çıkarılması ve sertifikalandırılarak organik olarak pazarlanması, elde edilecek manda yoğurdu, manda kaymağı, mozerella peyniri gibi ürünlerin turistik ürün olarak değerlendirilmesine ve bölgenin kalkınmasına etki edecektir. Ayrıca bölgede kırsal turizm ve organik hayvancılık faaliyetleri içinde manda yetiştiriciliği alternatif üretim biçimi olarak sunulabilir. Üreticilerin örgütlenerek üretim ve pazarlama konularındaki sıkıntıları giderilmelidir. Diğer taraftan, manda et ve sütü ile bunlardan elde edilen ürünlerin lezzet ve sağlık açısından üstünlükleri medya ve kamu spotları ile tüketicilere anlatılarak talep oluşturulmalıdır. Tarım ve Orman Bakanlığının destekleri, üretici birliklerinin faaliyetleri, üniversite ve araştırma enstitülerinde manda yetiştiriciliği ve 1slahı konularında yapılan çalışmaların artmasıyla manda sayısı son yıllarda çoğalmış olup, bu artışın sürdürülebilirliği sağlanmalıdır. Manda yetiştiriciliği, KOP bölgesi için gelişebilen bir işletmecilik ve artan hayvansal gıda ihtiyacının karşılanması açısından da önemli bir potansiyel olarak görülmektedir.

\section{Kaynakça}

[1] Anonim. KOP Bölge Kalkınma İdaresi Başkanlığı, 2020a. http://www.kop.gov.tr/. (erişim tarihi: 15.01.2020).

[2] Anonim. Tarım İstatistikleri, TUIK, 2020b. (www.tuik.gov.tr), (erişim tarihi: 25.03.2020)
[4] Anonim. KOP Bölge Kalkınma İdaresi Başkanlığı, 2018. KOP Bölgesel SosyoEkonomik Göstergeler (Nisan-2018). http://www.kop.gov.tr/. (erişim tarihi: 15.01.2020).

[5] Soysal Mí., Kök S., Gürcan EK. Mandalarda alyuvar potasyum polimorfizmi üzerine bir araştırma, Tekirdağ Zir. Fak. Derg 2005; 2(2): 189193.

[6] Atasever S., Erdem H. Manda yetiştiriciliği ve Türkiye'deki geleceği. OMÜ Ziraat Fak. Dergisi 2008; 23(1): 59-64.

[7] Şekerden Ö. Büyükbaş Hayvan Yetiştirme Kitabı (Manda Yetiştiriciliği). Temizyürek Matbaacılık AntakyaHatay. 2001.

[8] Anonim. Manda yetiştiriciliği hakkında genel bilgiler, 2008. Tarım ve Köyişleri Bakanlığ 1 Kocatepe Tarımsal Araştırma Enstitüsü. Afyon.

[9] Soysal Mİ. Manda ve ürünleri üretimi. Ders Notları Namık Kemal Üniversitesi Ziraat Fakültesi

Zootekni Bölümü, ISBN NO: 978-99445405-3-7, 237s, Tekirdağ. 2009.

[10] Küçükkebapçı M., Şahin M. Dünyada ve Türkiye'de Mandacilı Semineri. Kocatepe Tarımsal Araştırma Enstitüsü, Afyon. 2002.

[11] Yılmaz S. Afyonkarahisar yöresi manda yetiştiriciliği: Küçükçobanlı Köyü örneği (Yüksek lisans tezi), Adnan Menderes Üniversitesi, Fen Bilimleri Enstitüsü. 2013.

[12] Şahin A., Ulutaş Z. Anadolu mandalarının değişik metotlara göre tahmin edilen süt verimleri üzerine bazı çevresel faktörlerin etkilerinin belirlenmesi, Kafkas Üniversitesi Veteriner Fakültesi Dergisi 2014; 20(1): 79-85.

[13] Soysal MI., Tekerli M., Daşkıran İ. Anatolian water buffaloes husbandry in Turkey, Buffalo Bulletin 2013; 32(1): 293-309.

[14] El-Salam MHA., El-Shibiny SA. Comprehensive review on the composition and properties of buffalo milk, Dairy Science \& Technology 2011; 91(6): 663. 
[15] Wanapat M., Chang KS. World buffalo production: challenges in meat and milk production and mitigation of methane emission, Buffalo Bulletin 2013; 32(Special Issue 1): 1-21.

[16] Aköz M., Arik D., Kul M., Çelik B. Buffalo breeding: buffalo breeding in Turkey from past to today, International Journal of Scientific and Technological Research 2017. www.iiste.org ISSN 2422-8702 (Online) 3(2): 9-14.

[17] Borghese A. Development and perspective of buffalo and buffalo market in Europe and Near East, 9th World Buffalo Congress, Buenos Aires 2010; pp. 25-28.

[18] Oysun G. Süt kimyas1 ve biyokimyas1. OMÜ Yayınları, 1987. Yayın no: 18, 194.

[19] Demirci M., Yüksel AN., Soysal Mİ. Memeden mamül maddeye süt, Hasad Yayınc1lık Hayvancılık Serisi 1991; 364.

[20] Şahin G. Türkiye zirai hayatında manda (bubalus bubalis) yetiştiriciliği ve manda ürünlerinin değerlendirilmesi, İstanbul Üniversitesi Edebiyat Fakültesi Coğrafya Derg 2015; 31.

[21] Ermetin O. Husbandry and sustainability of water buffaloes in Turkey, Turkish Journal of Agriculture-Food Science and Technology 2017; 5(12): 1673-1682.

[22] Borghese A. Buffalo livestock and products in Europe, Buffalo Bulletin 2013; 32(Special Issue 1): 50-74. 